\title{
CHARACTERIZATION OF THE WEED SEED BANK IN ZERO AND CONVENTIONAL TILLAGE IN CENTRAL CHILE
}

\author{
Rosa Peralta Caroca ${ }^{1}$, Paola Silva Candia ${ }^{1 *}$, and Edmundo Acevedo Hinojosa ${ }^{1}$
}

\begin{abstract}
We studied the abundance, species composition, and depth distribution of the weed seed bank under no-tillage (NT) and conventional tillage (CT) at two sites, A and B. Soil samples were taken at three soil depths (0-2, 2-5, and 5-15 $\mathrm{cm})$. Germinated, dormant, and total seeds were counted. The total number of seeds was higher $(\mathrm{p} \leq 0.05)$ under CT treatment at the two sites $\left(\mathrm{CTA}=5175\right.$ seeds $\mathrm{m}^{-2}, \mathrm{NTA}=3250$ seeds $\mathrm{m}^{-2}, \mathrm{CTB}=33770 \mathrm{~m}^{-2}$, and $\mathrm{NTB}=22437$ seeds $\left.\mathrm{m}^{-2}\right)$. The number of viable, dormant, and germinated seeds was also higher $(\mathrm{p} \leq 0.05)$ in $\mathrm{CT}$ at the two sites. The percentage of viable seeds was low with $37 \%$ (CTA), 34\% (CTB), $21 \%$ (NTA), and $8 \%$ (NTB). Viable seeds of Chenopodium album L. (CHEAL) dominated in the two trials with 67\% (CTA), 20\% (NTA), 96\% (CTB), and 77\% (NTB). In a principal component analysis, PC1 separated viable seeds of weed species according to tillage and PC2 separated weed species according to sites. Роа аппиа $\mathrm{L}$. was the most important species associated with NT followed by Cichorium intybus L., and Sonchus while Euphorbia helioscopia L. and Echinochloa crus-galli (L.) P. Beauv. were associated with CT.
\end{abstract}

Key words: No-tillage, species composition, abundance, depth distribution.

\section{INTRODUCTION}

Weed control is becoming more difficult in conservation tillage because of a decrease or complete elimination of mechanical operations (Forcella et al., 2004), and for this reason, it is important to gain knowledge about the soil weed seed bank. This seed bank represents the main source of annual weed infestation and constitutes a weed seed reservoir in agricultural production systems (Montaldo, 1995). The soil tillage system affects the horizontal and vertical distribution of weed seeds in the soil (Yenish et al., 1992; Buhler et al., 1997; Chauhan et al., 2006) and determines weed emergence and species composition (Buhler et al., 1997; Sosnoskie et al., 2006; Murphy et al., 2006).

No soil inversion in direct planting leads to seed accumulation near the soil surface, and creates conditions promoting seed germination when combined to a higher soil water content induced by the presence of crop residues on the top of the soil (Buhler, 1992). Around $60 \%$ of total

${ }^{1}$ Universidad de Chile, Facultad de Ciencias Agronómicas, Santa Rosa 11315, La Pintana, Santiago, Chile.

*Corresponding author (psilva@uchile.cl).

Received: 22 April 2010.

Accepted: 11 October 2010. weed seeds is found between 0 and $5 \mathrm{~cm}$ soil depth, and weed seed concentration decreases logarithmically with soil depth (Ball, 1992; Yenish et al., 1992; Clements et al., 1996; Buhler et al., 1997; Chauhan et al., 2006). Residues from previous crops on top of the soil may decrease or favor conditions leading to weed seed germination. Some associated factors may decrease weed emergence, such as low light intensity, lower temperature close to the soil surface, and residues that release phytotoxic compounds. Therefore, weed species changes with soil tillage. Wicks et al. (1994) found that weed establishment was reduced by $14 \%$ for every $\mathrm{Mg}$ of wheat residue per hectare, and Buhler et al. (1997) found that the density of Abutilon theophrasti Medik. and Amaranthus retroflexus L. was $70 \%$ higher in conventional tillage than in direct drilling.

Seed bed preparation in conventional tillage inverts the soil, eliminates previously germinated seeds, and buries seeds distributed on the soil surface; previously buried seeds are also returned to the soil surface. Seeds returned to the soil surface will germinate and infest the crop if they have favorable environmental conditions. Almost all germinating seeds are concentrated in the upper $2.5 \mathrm{~cm}$ of soil (Fogliatti, 2003).

One characteristic that influences the presence of weeds according to tillage is their ability to germinate 
deep in the soil. Setaria faberi R.A.W. Herrm. germinated best between 1 and $4 \mathrm{~cm}$ of soil while below $6 \mathrm{~cm}$ germination notably decreased (by $50 \%$ or more) while only $18 \%$ of A. theophrasti seeds germinated in the upper $6 \mathrm{~cm}$ of soil (Buhler et al., 1997). Largesized annual weed seeds, such as Xanthium strumarium L. and A. theophrasti dominate in conventional tillage while the population of annual weed seeds with small seeds increases in direct drilling, including Setaria spp., Chenopodium album L., Amaranthus spp. (Wrucke and Arnold, 1985), and Taraxacum officinale F.H. Wigg. aggr. (Yenish et al., 1992; Mulugeta and Stoltenberg, 1997).

Chilean literature shows that research about zero tillage has mainly focused on changes in physical, chemical, and biological soil properties when changing tillage practices from CT to NT (Alvear et al., 2005; Borie et al., 2006; Martínez et al., 2008). However, little is known about changes in the weed seed bank that can be induced by adopting NT, which may result in future problems caused by weeds (Forcella et al., 2004). The objective of this study was to characterize the weed seed bank in a wheat-maize rotation grown at two sites under direct and conventional tillage. Abundance, species composition, depth distribution, germination, and viability of weed seeds were determined at three soil depths $(0-2,2-5$, and $5-15 \mathrm{~cm})$.

\section{MATERIALS AND METHODS}

\section{Edafoclimatic site characteristics}

The seed bank study was carried out at two sites in the Antumapu Experimental Station, Universidad de Chile

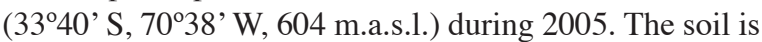
a sandy clay loam Mollisol, Santiago Series (coarse loamy over sandy, skeletal, mixed, thermic Entic Haploxeroll). Its texture is sandy loam with good internal drainage, medium depth $(60 \mathrm{~cm}), 2 \%$ organic matter, and $\mathrm{pH} 8$. The climate is Mediterranean with $330 \mathrm{~mm}$ annual rainfall with $80 \%$ falling between May and August, and the mean temperature varies from a maximum of $28.7^{\circ} \mathrm{C}$ in January to a minimum of $3.4{ }^{\circ} \mathrm{C}$ in July (Santibáñez and Uribe, 1990).

Each site was cropped with a wheat-maize (Triticum turgidum L. subsp. durum (Desf.) Husn.) and (Zea mays L.) rotation where two tillage systems were compared, no-tillage (NT) and conventional tillage (CT). Sites had a different cropping history and the time at which NT was introduced varied. At site A, the study of NT vs. CT started in 2000 (NTA and CTA) and in 1997 at site B (NTB and CTB). The experimental design at each site was a randomized complete block with three replicates; plot size was 10 x $20 \mathrm{~m}$ and $10 \times 10 \mathrm{~m}$, respectively.

\section{Crop management}

Crops at the two sites had the same agronomic management. Tillage took place in autumn for wheat planting and during winter for maize sowing. The CT treatment was tilled with a moldboard plow at $20 \mathrm{~cm}$ depth followed by two passes with a disc harrow, residue was buried, and the soil surface was left unprotected. Wheat in the NT treatment was planted on maize residue of the previous crop that was cut into $10-\mathrm{cm}$ pieces with a residue cutter. Wheat, durum wheat (T. turgidum subsp. durum) cv. "Llareta INIA", was planted in June at 150 $\mathrm{kg} \mathrm{ha}^{-1}$ and a distance of $17.5 \mathrm{~cm}$ between rows. It was fertilized with $60 \mathrm{~kg} \mathrm{~N}^{-1}$ as urea and $35 \mathrm{~kg} \mathrm{P}_{2} \mathrm{O}_{5} \mathrm{ha}^{-1}$ as triple superphosphate at sowing and $90 \mathrm{~kg} \mathrm{~N} \mathrm{ha}^{-1}$ as urea at first node. Prior to maize sowing, residue of the previous crop (durum wheat) was cut with a horizontal residue cutter. Maize was planted during the second half of September. The two sites were planted with the hybrid Mexico (Semameris, Santiago, Chile). Planting density was 110000 plants ha $^{-1}$ at a distance of $75 \mathrm{~cm}$ between rows. Maize was fertilized with $250 \mathrm{~kg} \mathrm{~N} \mathrm{ha}^{-1}$ (urea) and $60 \mathrm{~kg} \mathrm{P}_{2} \mathrm{O}_{5}$ ha $^{-1}$ (triple superphosphate) at sowing and 250 $\mathrm{kg} \mathrm{N} \mathrm{ha}^{-1}$ (urea) at the 8 leaf fully expanded stage. Pests and diseases were controlled with customary treatments. All crops were planted with a Semeato SHM13/15 no-till planter (São Cristóvão, Rio Grande do Sul, Brazil) and sprinkler-irrigated with deep well water.

The same herbicides were employed in each tillage system, except roundup (glyphosate) which was applied in NT at a dose of $4 \mathrm{~L} \mathrm{ha}^{-1}$ prior to planting. 2,4-D (1 $\mathrm{L} \mathrm{ha}^{-1}$ ) was used in wheat and On Duty (imazapic + imazapyr) in maize at a dose of $114 \mathrm{~g} \mathrm{ha}^{-1}$ along with Dash HC $\left(0,125 \mathrm{~L} \mathrm{ha}^{-1}\right) 43 \mathrm{~d}$ after planting.

\section{Soil sampling}

Soil sampling to determine the weed seed bank was carried out in the maize crop inter-row during February and March 2005 prior to harvest. A composite sample of 20 subsamples was obtained in each plot at the two sites (A and B) for three soil depths $(0-2,2-5$, and 5-15 cm), and every soil subsample was $6 \times 9 \mathrm{~cm}(108,162$, and $540 \mathrm{~cm}^{3}$, respectively). The first subsample was obtained at random in the plot and other subsamples were obtained by walking in zigzag fashion from the first subsample location. Composite samples from each treatment were mixed into one per treatment in each experiment. Samples were taken to a greenhouse where they were extended, air-dried, and shaded from direct sunlight at room temperature. Finally, samples were stored in paper bags to prevent seed germination during storage (Álvarez, 2003; Fogliatti, 2003) 


\section{Experimental design}

We used a randomized complete block design with four replicates to evaluate the various weed sources, two tillage systems (NT and CT), three soil depths (0-2, 2-5, and $5-15 \mathrm{~cm})$ at two sites, A and B. The composite soil sample from each source was divided into four parts, each one a replicate of the weed seed evaluation.

\section{Evaluations}

Quantification of weed seeds was performed by mixed methods in two phases (Gross, 1990; Fogliatti, 2003; Forcella et al., 2004). The first phase was germination and emergence of the sample seeds and consisted in providing adequate light, humidity, and temperature conditions to the soil samples so that their active seeds could geminate and emerge. Each composite soil sample was divided into four plastic trays $\left(504 \mathrm{~cm}^{3}\right)$, and placed in the greenhouse under natural light conditions and a range of temperatures that varied between 10 and $30{ }^{\circ} \mathrm{C}$. Two 45 -d germination cycles were carried out. Parallel to the germination test, plants were harvested, herborized, and conserved in reference collections (Gross, 1990; Álvarez, 2003). At the end of the first cycle, soil was turned under and a second germination cycle started. At the end of the second germination cycle, the soil sample of each plastic tray was dried at ambient temperature, crushed, and sieved with 0.495 , 1 , and $2 \mathrm{~mm}$ sieves (Álvarez, 2003). Four soil fractions were obtained ( $>2$, between 1 and 2, between 0.5 and 1 . and $<0.5 \mathrm{~mm}$ ).

The second phase was the direct visual separation of weed seeds by washing them through sieves. Each soil fraction was washed with water to separate the seeds from the soil through a fine nylon sieve resulting in a mixture of seeds, organic matter, and soil particles. The mixture was left at ambient temperature for $24 \mathrm{~h}$ and put into paper bags to count the weed seeds. Seeds were manually extracted with tweezers and a magnifying glass (Fogliatti, 2003). Keys developed by Kogan (1992), Matthei (1995), and Espinoza (1996) were used to identify the genera and species along with the reference collection from the trays. The collected seeds were put in Petri dishes with filter paper soaked with distilled and sterilized water. Petri dishes were placed in a germination chamber for $22 \mathrm{~d}$ at $25^{\circ} \mathrm{C}$ with continuous light (Fogliatti, 2003). Germinated seeds were counted and ungerminated seeds were submitted to a viability test with 2,3,5 trifenilchloride tetrazolio at $1 \%$ according to the methodology described in the Manual of Tetrazolio Trials of the National Institute of Seeds and Nursery Plants (Moore, 1986). The test was performed in Petri dishes covered with filter paper, keeping the seeds for $24 \mathrm{~h}$ in an oven at $30^{\circ} \mathrm{C}$ in the dark (Gross, 1990; Martínez, 1991; Álvarez, 2003; Fogliatti, 2003; Forcella et al., 2004). Seeds that reacted positively to the test were classified as dormant and the rest as dead seeds. Total, viable, germinated, and dormant seed values were adjusted per unit area (per $\left.\mathrm{m}^{2}\right)$.

\section{Statistical analysis}

The variables studied had non-homogeneous variances and their distribution was not normal so data were submitted to a non-parametric ANOVA by the KruskalWallis test $(p \leq 0.05)$ and post-hoc Kruskal-Wallis multiple comparisons test. Results were then submitted to a principal component (PC) analysis with the InfoStat software (InfoStat, 2005). The PC analysis allowed identifying relationships between abundance and species composition in the banks, soil tillage, and experimental site.

\section{RESULTS}

\section{Seed abundance and depth distribution}

Total weed seeds. The total number of weed seeds at various soil depths for CT and NT treatments at sites $\mathrm{A}$ and $\mathrm{B}$ are shown in Table 1. The total abundance of weed seeds was significantly higher $(\mathrm{p} \leq 0.05)$ in CT than in NT at both sites. Continuous tillage had higher seed numbers at all depths, but were significantly higher ( $\mathrm{p} \leq$ 0.05 ) between $0-2 \mathrm{~cm}$ and $5-15 \mathrm{~cm}$ in CTB compared with NTB.

At site A, total numbers of seeds increased with increasing soil depth in both tillage systems while at site $\mathrm{B}$, there was practically no difference among soil depths.

Table 1. Total weed seeds at sites A and B under no-tillage and conventional tillage.

\begin{tabular}{lllcc}
\hline Soil depth & CTA & NTA & CTB & NTB \\
\cline { 2 - 5 } $\mathrm{cm}$ & \multicolumn{4}{c}{ Seeds $\mathrm{m}^{-2}$ soil } \\
$0-2$ & $807 \mathrm{ab}$ & $590 \mathrm{a}$ & $13813 \mathrm{c}$ & $7444 \mathrm{ab}$ \\
$2-5$ & $1218 \mathrm{bcd}$ & $840 \mathrm{abc}$ & $9582 \mathrm{ab}$ & $8403 \mathrm{ab}$ \\
$5-15$ & $3150 \mathrm{~cd}$ & $1820 \mathrm{~d}$ & $10375 \mathrm{bc}$ & $6590 \mathrm{a}$ \\
Total & $5175 \mathrm{~B}$ & $3250 \mathrm{~A}$ & $33770 \mathrm{~B}$ & $22437 \mathrm{~A}$ \\
\hline
\end{tabular}

CTA: conventional tillage at site A; NTA: no-tillage at site A; CTB conventional tillage at site B; NTB: no-tillage at site B.

Lowercase letters show significant differences $(\mathrm{p} \leq 0.05)$ between tillage systems and soil depth at each site separately.

Capital letters indicate significant differences $(\mathrm{p} \leq 0.05)$ between tillage systems at each site separately.

Viable seeds. The number of viable seeds was significantly higher $(\mathrm{p} \leq 0.05)$ in $\mathrm{CT}$ than NT at both sites, but more so at site $\mathrm{B}$ (Table 2). At site A, viable seed numbers increased with increasing soil depth in both tillage systems while, there was no difference among soil depths at site B. The viable seed group represented the lowest percentage of weed 
seeds in each tillage system with 37 and $34 \%$ in CTA and CTB, respectively, while in NTA and NTB it represented 21 and $8 \%$, respectively. NTB had the lowest percentage of viable weed seeds and the highest was CT at both sites, whereas NTA exhibited an intermediate behavior.

Table 2. Viable weed seeds and percentage of viable seeds of total seeds (in parentheses) at sites A and B under no-tillage and conventional tillage.

\begin{tabular}{|c|c|c|c|c|}
\hline Soil deptl & CTA & NTA & CTB & NTB \\
\hline $\mathrm{cm}$ & \multicolumn{4}{|c|}{${ }_{\text {Seeds } \mathrm{m}^{-2} \text { soil } \longrightarrow}$} \\
\hline $0-2$ & $322 \mathrm{bc}(40)$ & $138 \mathrm{a} \quad(23)$ & 4977b (36) & $391 \mathrm{a}(5)$ \\
\hline $2-5$ & $422 \mathrm{~cd}(35)$ & 192ab (23) & $2907 \mathrm{ab}(30)$ & $501 \mathrm{a}(6)$ \\
\hline $5-15$ & $155 \mathrm{~d}(37)$ & 335bcd (18) & $3725 b(36)$ & $780 \mathrm{a}(12)$ \\
\hline Total & 899B (37) & $665 \mathrm{~A} \quad(21)$ & $11609 \mathrm{~B}(34)$ & $1672 \mathrm{~A}(8)$ \\
\hline
\end{tabular}

CTA: conventional tillage at site A; NTA: no-tillage at site A; CTB: conventional tillage at site B; NTB: no-tillage at site B.

Lowercase letters show significant differences $(\mathrm{p} \leq 0.05)$ between tillage systems and soil depth at each site separately.

Capital letters indicate significant differences $(\mathrm{p} \leq 0.05)$ between tillage systems at each site separately.

Germinated seeds. The total number of germinated seeds was significantly higher $(\mathrm{p} \leq 0.05)$ in CT than in NT at both sites (Table 3), and this difference was greater at site B. At site A, the numbers of germinated seeds increased with increasing soil depth in both tillage systems while at site B, there was no difference among soil depths. The percentages of germinated seeds were 25 and $28 \%$ in CTA and CTB while in NTA and NTB it represented 18 and $4 \%$, respectively. NTB had the lowest percentage of germinated seeds and the highest was $\mathrm{CT}$ at both sites while NTA exhibited an intermediate behavior.

Table 3. Germinated seeds and percentage of germinated seeds of total seeds (in parentheses) at sites A and B under no-tillage and conventional tillage.

\begin{tabular}{|c|c|c|c|c|}
\hline Soil deptl & CTA & NTA & СТВ & NTB \\
\hline $\mathrm{cm}$ & \multicolumn{4}{|c|}{$\longrightarrow$ Seeds $\mathrm{m}^{-2}$ soil } \\
\hline $0-2$ & $263 \mathrm{bc}(33)$ & $115 \mathrm{a} \quad(20)$ & 4017b (29) & $250 \mathrm{a}(3)$ \\
\hline $2-5$ & $333 c d(27)$ & $176 a b(21)$ & $1977 \mathrm{ab}(21)$ & $295 \mathrm{a}(4)$ \\
\hline 5-15 & $695 d(22)$ & 305bcd (17) & $3360 \mathrm{~b}(32)$ & $415 \mathrm{a}(6)$ \\
\hline Total 12 & $291 B(25)$ & 596A (18) & 9354B (28) & $960 \mathrm{~A}(4)$ \\
\hline
\end{tabular}

CTA: conventional tillage at site A; NTA: no-tillage at site A; CTB: conventional tillage at site B; NTB: no-tillage at site B.

Lowercase letters show significant differences $(\mathrm{p} \leq 0.05)$ between tillage system and soil depth at each site separately.

Capital letters indicate significant differences $(\mathrm{p} \leq 0.05)$ between tillage systems at each site separately.
Dormant weed seeds. The number of dormant weed seeds was significantly higher $(\mathrm{p} \leq 0.05)$ in CT than in NT at both sites (Table 4). The percentage of dormant weed seeds showed the same behavior at both sites and soil depth was not significant.

Table 4. Dormant seeds in A and B sites under no-tillage (NT) and conventional tillage (CT).

\begin{tabular}{|c|c|c|c|c|}
\hline Soil depth & CTA & NTA & CTB & NTB \\
\hline $\mathrm{cm}$ & & $-\mathrm{Sec}$ & $\mathrm{c}^{-2}$ soil- & \\
\hline $0-2$ & $59 \mathrm{ab}$ & $23 a$ & $960 \mathrm{c}$ & $141 \mathrm{a}$ \\
\hline $2-5$ & $89 b$ & $17 \mathrm{a}$ & 930bc & $206 a b$ \\
\hline $5-15$ & $460 \mathrm{~b}$ & $30 \mathrm{a}$ & $365 \mathrm{abc}$ & $365 a b c$ \\
\hline Total & $608 \mathrm{~B}$ & $70 \mathrm{~A}$ & 2255B & $712 \mathrm{a}$ \\
\hline
\end{tabular}

CTA: conventional tillage at site A; NTA: no-tillage at site A; CTB: conventional tillage at site B; NTB: no-tillage at site B.

Lowercase letters show significant differences $(\mathrm{p} \leq 0.05)$ between tillage systems and soil depth at each site separately.

Capital letters indicate significant differences $(\mathrm{p} \leq 0.05)$ between tillage systems at each site separately.

\section{Species composition}

There were 13 species among the viable seeds, 12 were annuals (eight summer and four winter), and one species was perennial. Based on morphology, there were 11 dicots and 2 monocots. The dominant species was Chenopodium album L. (CHEAL) at the two sites (Table 5) with $67 \%$ viable seeds in CTA, $20 \%$ in NTA, $96 \%$ in CTB, and $77 \%$ in NTB. Other important species were Veronica persica Poir. (VERPE), Poa annua L. (POAAN), Datura stramonium L. (DATST), Polygonum aviculare L. (POLAV), Hirschfeldia incana (L.) Lagr.-Foss. (HISIN), and Euphorbia helioscopia L. (EPHHE).

Figure 1 shows principal component analysis applied to the data. Two groups of species related to tillage systems were separated by PC1. Species from CT are in the right quadrant and those species common to NT are in the left quadrant. PC2 separated the species according to sites. Species associated to site B are in the upper part of the figure and those associated with site $\mathrm{A}$ are in the lower part.

Associated species in each tillage system were the following: NT with the species POAAN, Cichorium intybus L. (CICIN), and Sonchus spp. (S); CT with EPHHE and Echinochloa crus-galli (L.) P. Beauv. (ECHCG). Associated species at each site were the following: Site $\mathrm{B}$ with the CHEAL and DATST species; at site A with Anthemis cotula L. (ANTCO), POLAV, VERPE, and HISIN. 


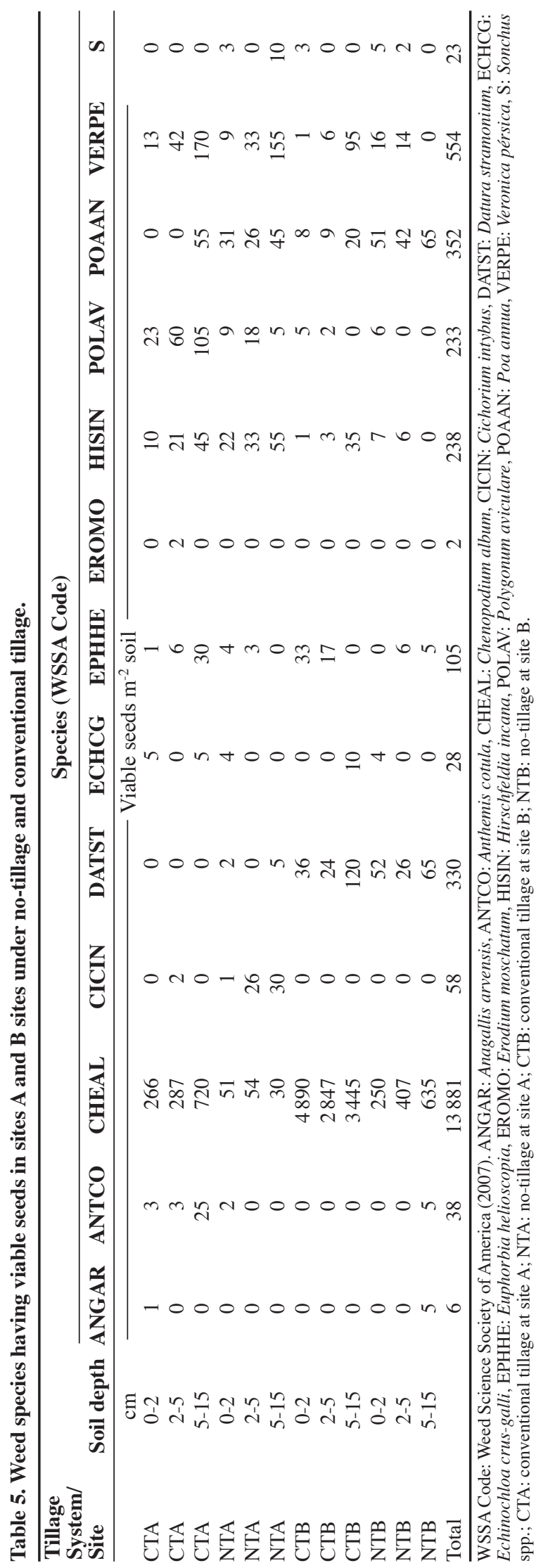

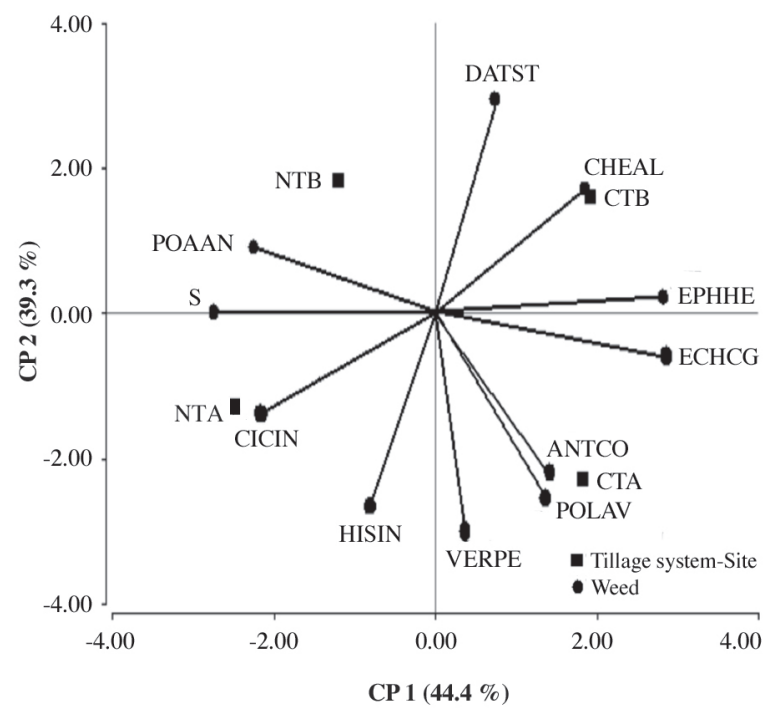

NT: no-tillage; CT: conventional tillage; A: site A; B: site B. Measured variables are represented by vectors from the center (0.0). ANTCO: Anthemis cotula, CHEAL: Chenopodium album, CICIN: Cichorium intybus, DATST: Datura stramonium, ECHCG: Echinochloa crusgalli, EPHHE: Euphorbia helioscopia, HISIN: Hirschfeldia incana, POAAN: Poa annua, POLAV: Polygonum aviculare, S: Sonchus spp., VERPE: Veronica persica.

\section{Figure 1. Biplot showing the principal components for the number of viable seeds per species.}

\section{DISCUSSION}

\section{Seed abundance}

The total number of weed seeds, as well as the number of viable, germinated, and dormant seeds was significantly lower ( $\mathrm{p} \leq 0.05)$ in NT at the two sites, and this agrees with results reported by Clements et al. (1996) for the upper 15 $\mathrm{cm}$ of soil (800 seeds $\mathrm{m}^{-2}$ under no-tillage and 2667 seeds $\mathrm{m}^{-2}$ under moldboard plow after a 7-yr maize-soybean rotation) in southern Ontario, Canada. Similarly, Murphy et al. (2006) found 8000 seeds $\mathrm{m}^{-3}$ under NT and 49000 seeds $\mathrm{m}^{-3}$ under CT after $6 \mathrm{yr}$ of tillage treatments in Ontario. On the other hand, the percentage of viable seeds decreased in NT, especially in experiments where NT was used for longer periods. The difference in the seed bank through tillage may be that NT keeps a higher proportion of seeds at the soil surface where they are eaten by herbivores, destroyed by parasites, or subjected to the direct action of herbicides (Clements et al., 1996; Buhler et al., 1997; Murphy et al., 2006). Murphy et al. (2006) found that NT induced a higher herbivorous activity and greater infection by pathogens on weed seeds. The lower seed abundance with soil depth in NT can be explained by the lack of soil inversion and the concomitant loss in seed viability. An important part of the seeds of the seed bank are incorporated into the soil with $\mathrm{CT}$ and returned to the soil surface in future tillages where 
they germinate. The moldboard plow tends to distribute the seeds uniformly in the soil profile (Ball, 1992; Yenish et al., 1992; Buhler et al., 1997).

A significantly lower number of viable and dormant seeds was found in NT, which was significantly lower ( $\mathrm{p} \leq$ 0.05) than CT at the two sites, and the lowest percentage of viable seeds was in the experiment with the longest period of NT. The lower abundance of viable seeds in NT has also been reported by Swanton et al. (2000) and Clements et al. (1996) who argue that weed seeds in NT are concentrated on or near the soil surface where they are subjected to dehydration and have less available water to germinate (Clements et al., 1996; Buhler et al., 1997), thus promoting the loss of viability. The number of dormant seeds also decreased in NT; therefore, after some time the NT weed seed reservoir should be exhausted. The results of this study show that unlike CT, an adequate use of herbicides and rotations in NT reduces the weed seed bank.

\section{Species composition}

The same viable species were generally found across tillage treatments for 12 species (11 annuals and 1 perennial), except EROMO with a few seeds in CTA. It is possible that the buffering effect of the weed seed bank was still operative due to the longevity of many weed seed species that act as a biodiversity reservoir of flora (Bàrberi et al., 1998).

The greater number of annual dicots found in this study is probably related to when the soil samples were taken. Soil was sampled in February and March, summer annuals set seed in summer/autumn and winter annuals in spring/summer, but there are species that can germinate at any time of the year depending on environmental conditions (Kogan, 1992). Felix and Owen (2001) found that the weed seed bank population density changed with the year and sampling time, and tended to increase in autumn and decrease in spring. Several summer annuals have a high dormancy rate during autumn that decreases during the winter and increases again during the summer unlike what occurs with winter annual species. Weed emergence in the field normally occurs when dormancy levels in the seed weed population are at a minimum (Batlla and Benech-Arnold, 2007).

Chenopodium album (CHEAL) was the dominant species in this study with CTA (67\%), CTB (96\%), NTB (77\%), and NTA (20\%). Although this species is not clearly associated with any tillage system, it tends to increase in CT. It germinates better in fertile soils that are rich in organic matter with abundant nitrogen and can germinate in extreme drought conditions (Duran and Pérez, 1984). Chenopodium album and Amaranthus spp. made up almost $82 \%$ of the seed bank in a maize monocrop and in a maize-soybean rotation managed under CT and NT (Felix and Owen, 2001).
The weed seed bank in CT was associated to EPHHE and ECHCG. Euphorbia helioscopia and CHEAL are summer dicot species and ECHCG is a summer monocot species. Fogliatti (2003) found the following as dominant species in CT: Amaranthus spp. (29\%), Portulaca oleracea L. (17\%), CHEAL (17\%), Rumex spp. (11\%), Solanum nigrum L. (10\%), Digitaria sanguinalis (L.) Scop. (8\%), and Echinochloa spp. (6\%). Yenish et al. (1992) found that CHEAL germination was $40 \%$ higher in CT than in NT. The highest germination percentages were found at soil depths of 9-19 cm and 0-9 cm when tilled with moldboard and chisel plows, respectively. On the contrary, Cardina et al. (2002) found that CHEAL dominated in NT when compared with CT.

In this study, the POAAN, CICIN, and S species were characteristic of the NT weed seed bank. Of these species, POAAN is the most significant because it is consistently more abundant at both sites. Burnside et al. (1986) found that plowing reduced monocot seed density more than broad leaf weeds, but Ball (1992) found that after $3 \mathrm{yr}$ of a maize monocrop under CT the dominant weeds were an annual monocot and two annual broad leaf weeds. Webster et al. (2003) reported that monocots represented 17 to $78 \%$ of the weed species in a weed seed bank of an NT system.

\section{Lessons for weed management under NT}

We have shown that it is possible to reduce the weed seed bank in a wheat-maize rotation cropped under notillage. Seeds on the soil surface are exposed to herbicides and herbivores while seeds buried deeply do not have the opportunity to finish their life cycle. It is therefore possible that the weed seed bank under no-tillage would be continuously depleted. An additional contributing factor to weed seed bank depletion is the high diversity of species cropped in the rotation under no-tillage (Liebman and Dyck, 1993), which increases the pressure against weeds by changes in crop management and weed environment from one season to the next. On the other hand, crop residues on top of the soil under no-tillage and high organic matter content in upper soil layers induce a lower availability of the applied herbicides (Isensee and Sadeghi, 1994). Therefore, when the base of weed control is the use of soil-active herbicides, chemical control will be less efficient and, in some cases, contribute to an increase of the weed seed bank under no-tillage (Sosnoskie et al., 2006).

\section{CONCLUSIONS}

In the weed seed bank of a wheat-maize rotation, the highest number of seeds, either total or viable, was found 
under conventional tillage. Chenopodium album L. (CHEAL) was a dominant species in both tillage systems and sites. Poa аппиа (POAAN) was the most important species associated with the NT weed seed bank followed by Cichorium intybus L. (CICIN) and Sonchus spp. (S), whereas the CT weed seed bank was dominated by Euphorbia helioscopia (EPHHE) and Echinochloa crusgalli (L.) P. Beauv. (ECHCG).

\section{ACKNOWLEDGEMENTS}

This study was partially financed by FONDECYT 1050565 project and the Universidad de Chile-SIRDSSAG-INDAP agreement. The authors thank Eduardo Martínez and Marco Garrido, graduate students of the Soil-Plant-Water Relations Laboratory of the Universidad de Chile, for their participation in the writing and discussion of this paper. The authors are grateful to the anonymous reviewers for their helpful comments and suggestions to improve this paper.

\section{RESUMEN}

Caracterización del banco de semillas de malezas en labranza cero y convencional en Chile central. Se estudió la abundancia, composición de especies y distribución en profundidad del banco de semilla de maleza en labranza convencional (CT) y cero labranza (NT) en dos sitios, A y B. Se tomaron muestras a tres profundidades de suelo $(0-2,2-5$ y $5-15 \mathrm{~cm})$. Se contaron semillas germinadas, dormantes y totales. La cantidad total de semillas fue significativamente mayor $(\mathrm{p} \leq 0,05)$ para ambos sitios $\left(\mathrm{CTA}=5175\right.$ semillas $\mathrm{m}^{-2}, \mathrm{NTA}=$ 3250 semillas $\mathrm{m}^{-2}$, CTB $=33770$ semillas $\mathrm{m}^{-2}$ y NTB $=22437$ semillas $\mathrm{m}^{-2}$ ). La cantidad de semillas viables, dormantes y germinadas fue significativamente mayor $(\mathrm{p} \leq 0.05)$ para ambos ensayos en CT que en NT. La mayor proporción de las semillas viables correspondió a germinadas. Se observó un bajo porcentaje de semillas viables $37 \%$ (CTA), 34\% (CTB), 21\% (NTA) and 8\% (NTB). Las semillas viables de Chenopodium album $\mathrm{L}$. (CHEAL) dominaron en ambos ensayos 67\% (CTA), $20 \%$ (NTA), $96 \%$ (CTB) y 77\% (NTB). En el análisis de componentes principales, el CP 1 separó las especies de malezas de semillas viables por sistema de labranza y el CP 2 separó por sitios. Poa annua L. fue la especie más importante asociada a NT seguida por Cichorium intybus L. y Sonchus, mientras que Euphorbia helioscopia L. y Echinochloa crus-galli (L.) P. Beauv. estuvieron asociadas a CT.

Palabras clave: siembra directa, composición de especies, abundancia, distribución en profundidad.

\section{LITERATURE CITED}

Alvear, M., A. Rosas, J.L. Rouanet, and F. Borie. 2005. Effect of different tillage systems on biological activities of an Ultisol from Southern Chile. Soil \& Tillage Research 82:195-202.

Álvarez, M. 2003. Cubierta vegetal y bancos de semillas en dos praderas adyacentes de la provincia de Osorno (X Región, Chile). 68 p. Tesis Ingeniero Agrónomo. Universidad Austral de Chile, Facultad de Ciencias Agrarias, Valdivia, Chile.

Ball, D. 1992. Weed seedbank response to tillage, herbicides, and crop rotation sequence. Weed Science 40:654-659.

Bàrberi, P., M. Macchia, A. Cozzani, and E. Bonari. 1998. Structure of weed seedbank communities under different management systems for continuous maize crop. Aspects of Applied Biology 51:289-296.

Batlla, D., and R. Benech-Arnold. 2007. Predicting changes in dormancy level in weed seed soil banks: implications for weed management. Crop Protection 26:189-197.

Borie, F., R. Rubio, J.L. Rouanet, A. Morales, G. Borie, and C. Rojas. 2006. Effects of tillage systems on soil characteristics, glomalin and mycorrhizal propagules in a Chilean Ultisol. Soil \& Tillage Research 88:253261.

Buhler, D. 1992. Population dynamics and control of annual weeds in corn (Zea mays) as influenced by tillage systems. Weed Science 40:241-248.

Buhler, D., R. Hartzler, and F. Forcella. 1997. Implications of weed seedbank dynamics to weed management. Weed Science 45:329-336.

Burnside, O.C., R.S. Moomaw, F.W. Roeth, G.A. Wicks, and R.G. Wilson. 1986. Weed seed demise in soil in weed-free corn (Zea mays) production across Nebraska. Weed Science 34:248-251.

Cardina, J., C.P. Herms, and D.J. Doohan. 2002. Crop rotation and tillage systems effects on weed seedbanks. Weed Science 50:448-460.

Chauhan, B., G. Gill, and C. Preston. 2006. Influence of tillage system on vertical distribution, seedling recruitment and persistence of rigid ryegrass (Lolium rigidorum) seed bank. Weed Science 54:669-676.

Clements, D.R., D.L. Benoit, S.D. Murphy, and C.J. Swanton. 1996. Tillage effect on weed seed return and seedbank composition. Weed Science 44:314-322.

Duran, J., y F. Pérez. 1984. Aspectos fisiológicos de la germinación de semillas. 245 p. Universidad Politécnica de Madrid, Escuela Técnica Superior de Ingenieros Agrónomos, Madrid, España.

Espinoza, N. 1996. Malezas presentes en Chile. 219 p. Instituto de Investigaciones Agropecuarias INIA, Centro Regional de Investigación Carillanca, Temuco, Chile. 
Felix, J., and M.D.K. Owen. 2001. Weed seedbank dynamics in post conservation reserve program land. Weed Science 49:780-787.

Fogliatti, J. 2003. Variabilidad sitio-específica del banco de semillas de malezas y su relación con otros factores del cultivo de maíz dulce (Zea mays). 44 p. Tesis Ingeniero Agrónomo. Pontificia Universidad Católica, Facultad de Agronomía e Ingeniería Forestal, Santiago, Chile.

Forcella F., T. Webster, y J. Cardina. 2004. Protocolos para la determinación de bancos de semillas de malezas en los agrosistemas. Capítulo 1. p. 3-22. In Labrada, R. (ed.) Manejo de malezas para países en desarrollo. Estudio FAO Producción y Protección Vegetal-120. Addendum I. FAO, Roma, Italia.

Gross, K. 1990. A comparison of methods for estimating seed number in the soil. Journal of Ecology 78:10791093.

InfoStat. 2005. Grupo InfoStat Versión Profesional versión 2005. Grupo InfoStat. Universidad Nacional de Córdoba, Facultad de Ciencias Agropecuarias, Argentina. Ed. Brujas, Córdoba, Argentina.

Isensee, A.R., and A.M. Sadeghi. 1994. Effects of tillage and rainfall on atrazine residue levels in soil. Weed Science 42:641-467.

Kogan, M. 1992. Malezas: ecofisiología y estrategias de control. 402 p. Colección Pontificia Universidad Católica de Chile, Santiago, Chile.

Liebman, M., and E. Dyck. 1993. Crop rotation and intercropping strategies for weed management. Ecological Applications 3:92-122.

Martínez, H. 1991. Relación entre la reserva de semillas del suelo y la composición botánica de una pradera anual mediterránea con distintos sistemas de talajeo. 66 p. Tesis Ingeniero Agrónomo. Universidad de Chile, Facultad de Ciencias Agrarias y Forestales, Santiago, Chile.

Martínez, E., J.P. Fuentes, P. Silva, S. Valle, and E. Acevedo. 2008. Soil physical properties and wheat root growth as affected by no-tillage and conventional tillage systems in a Mediterranean environment of Chile. Soil \& Tillage Research 99:232-244.

Matthei, O. 1995. Manual de las malezas que crecen en Chile. 545 p. Alfabeta Impresores, Santiago, Chile.
Montaldo, P. 1995. Manejo ecológico de las malezas. 165 p. Editorial Universidad Austral de Chile, Valdivia, Chile.

Moore, R. 1986. Manual de ensayos al tetrazolio. 92 p. Instituto Nacional de Semillas y Plantas de Vivero. Estación de Ensayos de Semillas. Ministerio de Agricultura, Pesca y Alimentación, Madrid, España.

Mulugeta, D., and D. Stoltenberg. 1997. Increased weed emergence and seed bank depletion by soil disturbance in a no-tillage system. Weed Science 45:234-241.

Murphy, S.D., D.R. Clements, S. Belaoussoff, P.G. Kevan, and C.J. Swanton. 2006. Promotion of weed diversity and reduction of weed seedbanks with conservation tillage and crop rotation. Weed Science 54:69-77.

Santibáñez, F., y J. Uribe. 1990. 65 p. Atlas Agroclimático de Chile. Regiones V y Metropolitana. Laboratorio de Agroclimatología, Facultad de Ciencias Agrarias y Forestales, Universidad de Chile, Santiago, Chile.

Sosnoskie, L.M., C.P. Hermes, and J. Cardina. 2006. Weed seedbank community composition in a 35 -yrold tillage and rotation experiment. Weed Science 54:263-273.

Swanton, C.J., A. Shrestha, S.Z. Knezevic, R.C. Roy, and B.R. Ball-Coelho. 2000. Influence of tillage type on vertical weed seedbank distribution in a sandy soil. Canadian Journal of Plant Science 80:455-457.

Webster, T., J. Cardina, and A. White. 2003. Weed seed rain, soil seedbanks, and seedling recruitment in notillage crop rotations. Weed Science 51:569-575.

Wicks, G., D.A. Crutchfield, and O.C. Burnside. 1994. Influence of wheat (Triticum aestivum) straw mulch and metolachlor on corn (Zea mays) growth and yield. Weed Science 42:141-147.

Wrucke, M.A., and W.E. Arnold. 1985. Weed species distribution as influenced by tillage and herbicides. Weed Science 33:853-856.

WSSA Code: Weed Science Society of America. 2007. Composite list of weeds as compiled by the standardized plant. Available at http://wssa.net/ Weeds/ID/WeedNames/namesearch.php (accessed November 2007).

Yenish, J., J. Doll, and D. Buhler. 1992. Effects of tillage on vertical distribution and viability of weed seed in soil. Weed Science 40:429-433. 